\title{
The Mechanism of the Development of Social Protection of Women in the Context of Domestic Violence
}

\author{
Ziyaeva Holida Omonkul kizi
}

\begin{abstract}
True equality of rights and freedoms can be found only on the basis of recognition of the value of each person, creation of stable conditions for self-development of the human intellect, the most complete realization of his creative potential and creative abilities, the comprehensive disclosure of essential forces and talents, which will ensure everyone's full contribution to the development of society. The transition of many countries to the information society - a society of intelligence, knowledge and thinking - creates basic opportunities for self-development and self-realization for every person. The need to adopt a gender strategy is determined by social problems caused by socio-economic and political transformations in Russia. Along with the opening of new prospects for the widespread use of human abilities, people are required to have high adaptive capabilities, which differ significantly between men and women. This article was written with the aim of developing a mechanism for the social protection of women in the context of gender-based violence. The following tasks are defined in the article: how to identify and justify the significance of the physiological premises of gender inequality; show the immanent essence of gender. inequalities in the history of the peoples of the world; to consider the dynamics of relations of inequality between the sexes; show the essence of violence as manifestations of gender inequality; develop a classification and analyze the types of gender-based violence; to explore the manifestation of gender-based violence in modern society. The article consists of from introduction, literature survey, methodology, recommendation, discussions, and conclusion.
\end{abstract}

Keywords: domestic violence, mechanism, risk factor, gender inequality, social protection, gender strategy, tools.

\section{INTRODUCTION}

The social discrimination of women is most expediently investigated in a double plan. On the one hand, it is a mass, social phenomenon that encompasses a large demographic community, consisting of different social, professional, age, status and official groups. On the other hand, it is a social process with a successive change in the state of an object.

The rights of women in general terms as the principle of equality between men and women are enshrined in the UN

Revised Manuscript Received on December 30, 2019.

* Correspondence Author

H.O. Ziyaeva*, Senior researcher of Faculty of Social Science, Department of Education, The National University of Uzbekistan after named Mirzo Ulugbek, Tashkent, Uzbekistan.

(C) The Authors. Published by Blue Eyes Intelligence Engineering and Sciences Publication (BEIESP). This is an open access article under the CC BY-NC-ND license (http://creativecommons.org/licenses/by-nc-nd/4.0/)
Charter, the Universal Declaration of Human Rights (1948), the International Covenant on Civil and Political Rights, the International Covenant on Economic, Social and Cultural Rights (1966), which prohibit discrimination on the basis of gender. Along with this, specific rights and freedoms of women are set forth and enshrined by the UN in the Convention on the Political Rights of Women (1952), the Convention on the Citizenship of Married Women (1957), the International Labor Organization Convention No. 100 on Equal Remuneration for Men and Women for Work of Equal Value (1951) and other documents. The UN is committed to the principle of equality between men and women, which means equality in dignity, the equal value of every human being, as well as their equality. The preamble to the UN Charter states that one of the main goals is the desire to "establish faith in the fundamental human rights, in the dignity and worth of the human person, in the equal rights of men and women." Given the continuing severity of the women's issue, the UN General Assembly adopted in 1967 a Declaration on the Elimination of Discrimination against Women. The most common international legal instrument on women's rights is the UN Convention on the Elimination of All Forms of Discrimination against Women (1979). The 1981 Convention legally enshrined and clarified the concept of "discrimination". According to the first article, the term "discrimination against women" means any distinction, exclusion or restriction on the basis of sex, which is aimed at weakening or negating the recognition, use or exercise by women, regardless of their marital status, on the basis of equal rights between men and women, the right person and fundamental freedoms in the political, economic, social, cultural, civil or other field.

The 19th century laid the foundation for women to become aware of their oppressed position. But the idea of the possibility of gender equality was never realized in practice.

\section{LITERATURE SURVEY}

The problem of studying the social status of women is of scientific interest to both foreign and domestic researchers. Among the fundamental works on the theory and history of feminism published in the West, the works of S. de Beauvoir [7] and B. Friedan [8, 9] are of particular importance.

Of great importance for enhancing the socio-political role of women were the research works of E.P. O.A. Xasbulatova [10], M.N. Hegai [11], who analyzed the situation of women and raised issues of rights, and equal opportunities for women and men in all fields of activity. 
A significant contribution to the development of the "women's issue" was made by N. Ajhigina [4], N.I.Abubikirova [4] and A.M. Kollontai [12]. According to A.M. Kollontai, the inequality of women was not caused by features of mental development, but by historical reality, when a woman gradually lost her social significance during the period of patriarchy and was completely dependent on the man. Under capitalism, this dependence was compounded by the contradiction between the growing role of women in capitalist production and the lack of equal social relations.

The social status of women in society is studied from various perspectives: discrimination and violence are reflected in the works of G. G. Sillaste [15], R. Mai [13], studied the inclusion of women in the labor market J.I. Babaeva [5] and M.E. Baskakova [6].

\section{METHODOLOGY}

The object of the study is gender-based violence.

The subject of analysis is gender-based violence as a manifestation of social inequality.

The aim of the study is to identify factors that determine gender inequality that engenders violence between the sexes.

The theoretical and methodological basis of the study is determined by the content of its goals and objectives, the specific approach and scientific position of the author. Of the methodological approaches, the most acceptable are the general scientific principles of cognition of social phenomena; interdisciplinary approach; methodological provisions and conclusions formulated by scientists in works on gender inequality, the manifestation of violence between the sexes.

In addition to these determining methodological principles, in the dissertation research the author also used more particular methods, namely: the historical method, which allows analyzing the origins of the problem; functional approach to the object and subject of research. When performing the work, the main provisions of the methods of system analysis and synthesis, statistical analysis, as well as empirical and theoretical generalization were used.

\section{THEORY AND DISCUSSION}

This state of affairs is explained by the fact that our society, like all historical civilizations, is patriarchal. This means that there is an ideological and political system in which the female is always subordinate to the male and in which men by force, direct suppression or through rituals, traditions, the law, language, customs, etiquette, education, division of labor, determine which role should or not should women play.

In international practice, there are important quantitative and qualitative standards for providing assistance to victims of domestic violence. The most progressive are the recommendations of the European Parliament, the Council of Europe Working Group on Combating Violence against Women, and the European Network of Women Against Violence Non-Governmental Organizations (WAVE). Abroad, public organizations have become interested in developing and implementing the principles and standards of quality of social services. It is understood that compliance with such standards will ensure the quality of assistance to victims in order to prevent further acts of violence against women and their children.

Victims of domestic violence are rarely willing to talk openly about their problem. Often they experience fear, guilt, shame and stop themselves from seeking help. Government agencies often do not have trained specialists because of the high staff turnover and are overloaded with other responsibilities. For example, quantitative standards, according to the recommendations of the European Parliament and the Council of Europe Working Group on Violence against Women, include one place of refuge per 10,000 inhabitants, one national toll-free helpline for women, working 24 hours a day, 7 days a week ( 24/7), etc. In 2011, only $36 \%$ of 44 European countries met these standards.

The novelty of the study is that:

- it has been revealed and justified that despite the democratization of relations and the declared equality between the sexes, in modern society gender inequality does not disappear and in the minds of most men a woman is still below the social hierarchy;

- revealed and proven, gender-based violence is perceived by society as an ordinary phenomenon that does not cause rejection and unequivocal judgment;

- It has been proven that gender-based violence is based on the traditional male perception of sexual superiority. The socio-demographic characteristics of men and the victim behavior of women do not significantly affect the spread of gender-based violence.

Gender-based violence is violence against members of the opposite sex in order to prove, confirm or demonstrate their sexual superiority. It is based on gender inequality. In modern societies and cultures, gender inequality implies the superiority of men over women. And if in some societies gender equality is declared, then none of them proclaims the dominance of women over men. Consequently, gender-based violence can only be considered violent actions of men against women. Only a man uses violence against a woman on the basis that he is a man and his gender gives him the right to do so. A woman, using violence against a man, does this not because of the recognition of the superiority of her gender, but because of the recognition of superiority over a particular man.

The fact that women in the country need additional protection has been discussed relatively recently - since 2016, when the Women's Committee began to speak publicly about violence, problems in respecting women's rights and the need to protect them. The Women's Committee itself was created in 1991 with the goal of working to enhance the role of women in society. However, the organization began to engage in specific tasks on this issue only 3 years ago. Until that moment, there were all kinds of restrictions on women in the country: for example, until 2017 women were limited in travel - in order to leave Uzbekistan, one had to receive an OVIR sticker (an analogue of an exit visa), which was given only with the permission of the parents or husband.

With the advent of the new government in 2016, Uzbekistan regularly makes attempts in one way or another to improve the situation with women's rights - at least from a legal point of view.

Published By: 
On April 23 this year, the Women's Committee of Uzbekistan uploaded a draft law "On guarantees of equal rights and opportunities for women and men," which should prevent discrimination on the basis of sex. The document explains what discrimination and gender equality are, describes future mechanisms for protecting these same rights, and establishes liability for violations.

Since this is still the first document of this kind, it dwells in detail on the explanation of gender equality (the absence of restrictions or privileges on the basis of sex), direct discrimination on the basis of sex (any difference, exclusion or restriction that is aimed at weakening or not recognizing the rights of men and women and human freedoms in all spheres of society's life), and for the first time in the laws of the country the concept of gender stereotypes appears (stable ideas of society about the differences in social roles between men and women, based on the idea of the superiority of either of the sexes).

According to the World Bank's Women, Business and Law 2018 report, Uzbekistan was one of the few countries in the world where protection from domestic violence is not spelled out in the legislation. To this day, this topic has not been raised either in the media, or in public, or in the speeches of officials [16].

In February 2018, President Shavkat Mirziyoyev signed a decree "On measures to radically improve activities in the field of supporting women and strengthening the institution of the family."[1] This decree criticized the current situation with women's rights and their participation in state affairs, and reformed the work of the Women's Committee. Even this year, the President of the Republic signed the decision "On measures to improve the system of social rehabilitation and adaptation, as well as the prevention of domestic violence" [3].

This decree also created the "Oila" research complex ("family" in Uzbek), which should strengthen marriages, study reproductive health, study the problems of modern families, compile lists of dysfunctional, etc. After the establishment of Oily, the center's employees walked through all regions of the country, talking with women about violence and the situation in their families. This center was also responsible for a strong family and divorces. If before, in order to dissolve a marriage, you had to take permission from the "makhalla" committee, but now "Oila" is responsible for this. The government's initiative to support women is certainly important in itself. However, the statement of the problem for the Center itself contains a contradiction - on the one hand, its task is to do everything to help women and work with difficult situations; on the other hand, they must do everything to save families. And often this leads to a greater conflict: where it is necessary to resolve the divorce, employees of the Center try to persuade the couple to live together a little more. The most useful point of the Decree was the establishment of the Fund for the Support of Women and Family at the Women's Committee and the Oil Center, which should further help women financially and legally. Now the fund is engaged in supporting women's entrepreneurship and the problems of low-income women. The foundation does not have an address on the Internet and can be accessed through the Women's Committee. By exerting violent acts against a particular man, a woman is not motivated in this way in relation to other men. On the contrary, a man who uses violence in any form against his wife, girlfriend or sister, realizing his sexual superiority, is just as motivated in relation to other women. He does not use violent acts against them only because of the existence of social prohibitions, which are laws and public opinion.

In 2018, the Women's Committee opened a hotline for women who experience violence. By calling the short number 1146, a woman can get the help of a doctor, psychologist or lawyer. According to Tanzila Narbaeva, chairman of the Women's Committee, opening a hotline, they did not expect such a wave of calls and requests for help. In the same year, the first shelters appeared in the country shelters for women suffering from domestic violence. Insiders say that at first the Committee did not understand the shelter's task correctly, and instead of providing asylum, they organized needlework clubs there.

The turning point in protecting women from violence was the adoption of the 2018 Law on the Prevention of Domestic Violence [2]. For the first time in the existence of independent Uzbekistan, a definition of the concept of psychological, economic, family and other types of violence has appeared. The discussion of proposals on this law ended in October 2018, and the further fate of the bill was unknown to anyone - over the past six months, the law remained in limbo.

On May 13, the Women's Committee published for discussion a new bill against violence, which should also protect women from oppression in the workplace and at home. This version of the bill is a revised but not adopted law on violence from last October.

One of the most important projects on violence and feminism was the public, "Do not be silent." A community on Facebook and Telegram appeared a year and a half ago to help survivors of violence and explain to others what sexism, depreciation, feminism, and so on are.

After some time, when a more or less loyal and understanding audience has already formed, an anonymous form has appeared in the project for those who have experienced, are experiencing or have witnessed domestic violence. "Do not be silent" talks about personal experiences, sharing experiences of victims.

Despite the recently published draft law on gender equality, which has already caused mixed reactions in society, it is necessary to fight against gender stereotypes more strongly.

\section{STATISTICS}

The United Nations Office in Uzbekistan supports the global call for the elimination of all forms of violence against women. Every year, a campaign called " 16 days of activism against gender-based violence" is held around the world. It begins on November 25, International Day for the Elimination of Violence against Women, and ends on December 10, International Human Rights Day, symbolically linking the two events to express the idea that violence against women is an act of violence against human rights [19]. 
In Uzbekistan, this campaign has been successfully carried out since 2011 under the motto "From peace in the home to peace on the planet", and members of the international community, civil society and government organizations come together to strengthen measures to support women.

In 2016, the international community took a new course towards equal, inclusive development, adopting a new sustainable development agenda: the Sustainable Development Goals. For the new development program to have a positive and significant impact, action must be taken to stop violence against women, which robs millions of women and girls of their fundamental rights and opportunities to contribute to economic and social progress in their countries.

"Around the world, every third woman is a victim of physical or sexual abuse. Stopping violence against women is a task that should be a priority for every person. This is not just a problem related to women, it is the duty of each of us," said the Head of the UN Office in Uzbekistan, Stefan Prisner [19].

The UN system is supporting the prevention and response to gender-based violence in more than 130 countries. One third of these countries are in crisis, which exacerbates the situation of women and girls. Global programs and policies to combat violence against women and girls have been developed to ensure sustainable development.

The adoption of appropriate laws and decisions served as the basis and changed the situation for the better. Already in this direction a lot of work has been done. According to the Internal Affairs of Uzbekistan, data compiled over the past 5 years [18].

Table I. The number of women (aged 15-49 years) who have ever had a close partner who have been physically and / or sexually abused by an active or previous close partner in the last 12 months [18].

\begin{tabular}{|c|c|c|c|c|c|}
\hline & 2014 & 2015 & 2016 & 2017 & 2018 \\
\hline $\begin{array}{l}\text { Republic } \\
\text { Uzbekistan }\end{array}$ & 344 & 252 & 324 & 268 & 185 \\
\hline $\begin{array}{l}\text { Republic of } \\
\text { Karakalpakstan }\end{array}$ & 26 & 27 & 22 & 20 & 14 \\
\hline \multicolumn{6}{|l|}{ regions: } \\
\hline Andijan & 8 & 5 & 4 & 5 & 1 \\
\hline Bukhara & 1 & 1 & 3 & 4 & 1 \\
\hline Jizzakh & 10 & 17 & 14 & 9 & 13 \\
\hline Kashkadarya & 4 & 2 & 3 & 1 & 4 \\
\hline Navoi & 4 & 1 & 1 & - & - \\
\hline Namangan & 1 & 2 & 1 & 2 & - \\
\hline Samarkand & 8 & 5 & 6 & 7 & 11 \\
\hline Surkhandarya & 16 & 18 & 15 & 13 & 7 \\
\hline Syrdarya & 11 & 27 & 18 & 12 & 4 \\
\hline Tashkent & 56 & 64 & 59 & 40 & 23 \\
\hline Fergana & 16 & 18 & 14 & 15 & 5 \\
\hline Khorezm & 63 & 52 & 47 & 40 & 33 \\
\hline Tashkent city & 120 & 13 & 117 & 100 & 69 \\
\hline
\end{tabular}

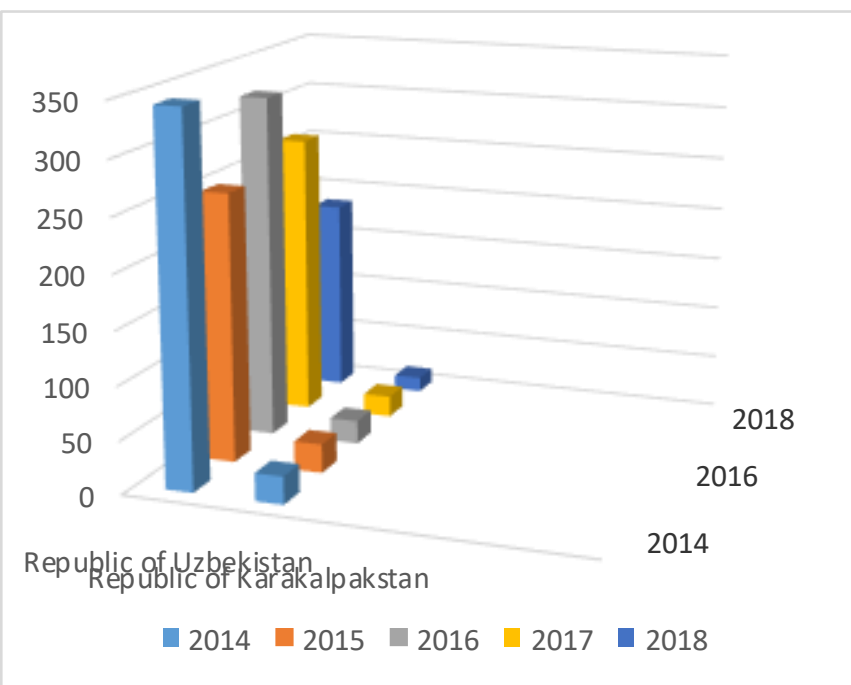

Fig.1. The number of women (aged $15-49$ years) who have ever had a close partner who have been physically and / or sexually abused by an active or previous close partner in the last 12 months (2014-2018 yy) [18]

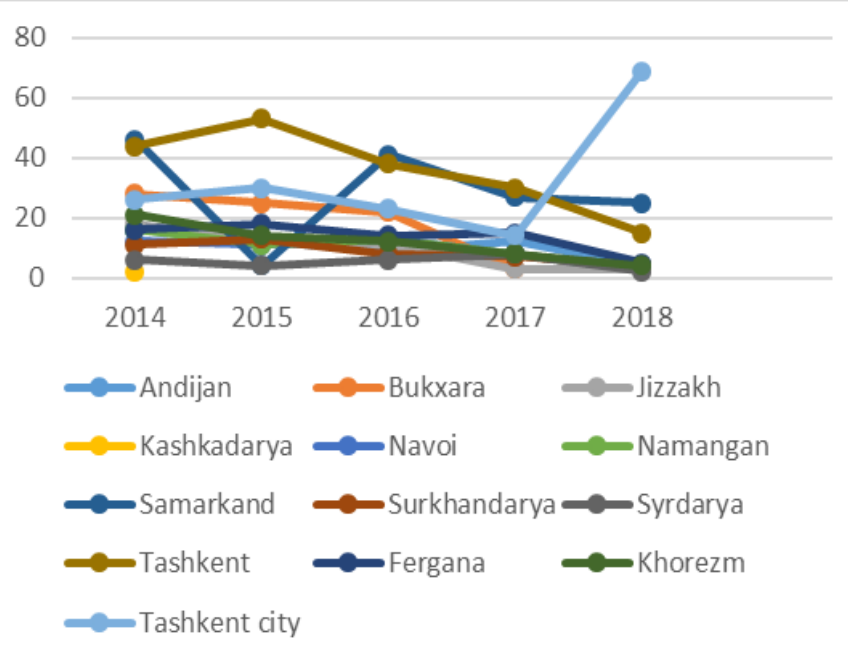

Fig.2. The number of women (aged 15-49 years) who have been subjected, since the age of 15 years, to sexual abuse by persons who were not close partners

(2014-2018) [18]

Table II. The number of women (aged 15-49 years) who have been subjected, since the age of 15 years, to sexual abuse by persons who were not close partners (2014-2018) [17]

(person)

\begin{tabular}{|l|l|l|l|l|l|}
\hline & $\mathbf{2 0 1 4}$ & $\mathbf{2 0 1 5}$ & $\mathbf{2 0 1 6}$ & $\mathbf{2 0 1 7}$ & $\mathbf{2 0 1 8}$ \\
\hline $\begin{array}{l}\text { Republic of } \\
\text { Uzbekistan }\end{array}$ & 282 & 272 & 227 & 189 & 108 \\
\hline $\begin{array}{l}\text { Republic of } \\
\text { Karakalpakstan }\end{array}$ & 20 & 21 & 18 & 18 & 15 \\
\hline \multicolumn{7}{|c|}{ regions: } \\
\hline Andijan & 16 & 12 & 9 & 12 & 4 \\
\hline Bukhara & 28 & 25 & 22 & 24 & 8 \\
\hline Jizzakh & 18 & 12 & 11 & 3 & 3 \\
\hline Kashkadarya & 2 & - & - & - & 4 \\
\hline Navoi & 12 & 11 & 13 & 8 & 3 \\
\hline Namangan & 16 & 12 & 12 & 15 & 3 \\
\hline
\end{tabular}

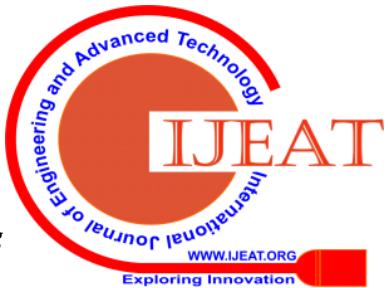




\begin{tabular}{|l|l|l|l|l|l|}
\hline Samarkand & 46 & 4 & 41 & 27 & 25 \\
\hline Surkhandarya & 11 & 13 & 8 & 7 & 4 \\
\hline Syrdarya & 6 & 4 & 6 & 8 & 2 \\
\hline Tashkent & 44 & 53 & 38 & 30 & 15 \\
\hline Fergana & 16 & 18 & 14 & 15 & 5 \\
\hline Khorezm & 21 & 14 & 12 & 8 & 4 \\
\hline Tashkent city & 26 & 30 & 23 & 14 & 13 \\
\hline
\end{tabular}

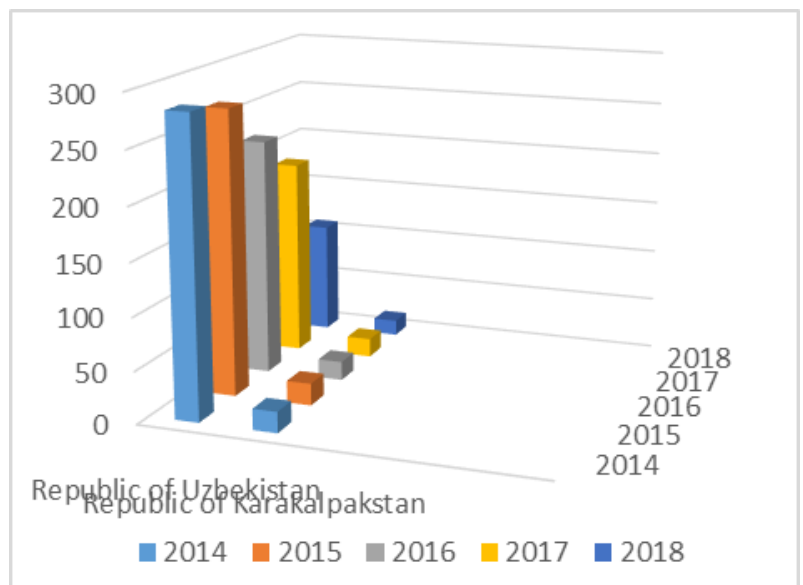

Fig.3. The number of women (aged 15-49 years) who have been subjected, since the age of 15 years, to sexual abuse by persons who were not close partners in Uzbekistan and Karakalpakstan (2014-2018)[17]

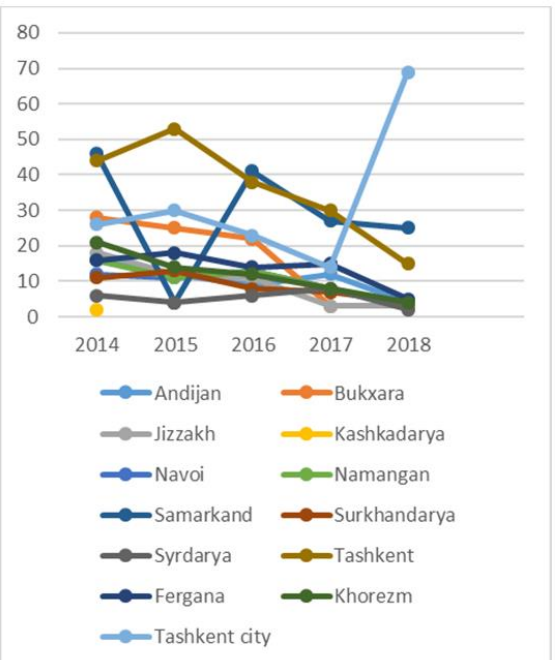

Fig.4. The number of women (aged $15-49$ years) who have been subjected, since the age of 15 years, to sexual abuse by persons who were not close partners in Uzbekistan and Karakalpakstan (2014-2018) [17]

Now that work has begun to achieve the new global sustainable development goals, we face the collective challenge of ending violence against women and girls by 2030. Each of us must do more so that no one is left behind. Every woman and girl has the right to live without gender discrimination and violence. This is necessary not only to ensure the dignity, rights and well-being of women and girls, but also for all of humanity and our common future.

\section{RECOMMENDATION AND CONCLUSION}

A gender equality strategy can in no way be understood as a strategy to eliminate gender differences. Its main purpose is to create political prerequisites and necessary social conditions for the fullest realization of the natural abilities of women and men in all spheres of social life with the aim of ensuring sustainable development of society.

The 19th century laid the foundation for women to become aware of their oppressed position. But the idea of the possibility of gender equality was never realized in practice.

This state of affairs is explained by the fact that our society, like all historical civilizations, is patriarchal. This means that there is an ideological and political system in which the feminine is always subordinate to the masculine and in which men by force, direct suppression or through rituals, traditions, law, language, customs, etiquette, education, division of labor determine what role should or not should women play.

Thus, it is precisely gender inequality, which primarily discriminates against women, that leads to gender-based violence, and domestic violence against women is only a separate type of gender-based violence, an integral part of gender-based violence against women. All over the world, women suffer violence only because they are female in a society that accepts and legitimizes discrimination against women. Therefore, gender-based violence is the basis, the foundation of violence against women in all areas.

To eliminate and identify gender-based violence, risk assessments must be used. Benefits of using risk assessment:

- Help victims and domestic violence workers develop more realistic safety plans.

- Help the criminal justice system determine which offender needs a higher bail, communicate the conditions of release, and develop more effective oversight strategies.

- Inform criminal justice professionals and service providers about domestic violence and provide a common language about risk factors.

- Assist offender treatment programs to select the number and type of treatment.

Several evidence-based tools have been developed to identify the potential for fatal violence, the risk of re-attack and the severity of the attack. Each tool was developed for a specific purpose, for use in certain conditions by certain practices, and each receives information from different sources or a combination of sources: public information (including past and present police reports), criminal history, past or present protective orders, violations of court orders or conditions, probation history, information from the offender and / or information from the victim.

The following are some examples of current tools used to predict risk.

Table III. Tools used for risk prediction

\begin{tabular}{|l|c|c|}
\hline$№$ & $\begin{array}{c}\text { Tools used for } \\
\text { risk prediction }\end{array}$ & Description \\
\hline
\end{tabular}




\begin{tabular}{|c|c|c|}
\hline 1 & $\begin{array}{l}\text { Hazard } \\
\text { Assessment } \\
\text { (DA) }\end{array}$ & $\begin{array}{l}\text { it is a clinical and research tool } \\
\text { developed by Dr. Jacqueline } \\
\text { Campbell. This tool is suitable in } \\
\text { confidential settings, or where } \\
\text { protocols and methods have } \\
\text { been established to ensure that } \\
\text { this information does not fall } \\
\text { into the hands of the offender. } \\
\text { The Hazard Rating Scale is "one } \\
\text { of the few published empirical } \\
\text { assessment tools for } \\
\text { psychometric properties, such as } \\
\text { retesting and reliability of } \\
\text { internal consistency." }\end{array}$ \\
\hline 2 & $\begin{array}{l}\text { Domestic } \\
\text { Violence } \\
\text { Screening } \\
\text { Device } \\
\text { (DVSI-R) }\end{array}$ & $\begin{array}{l}\text { DVSI can be filled out by } \\
\text { reviewing court protocols and } \\
\text { probation. It was designed to be } \\
\text { used as a screening for the risk of } \\
\text { domestic violence, followed by a } \\
\text { more intensive assessment if the } \\
\text { DVSI-R indicates a high level of } \\
\text { risk. }\end{array}$ \\
\hline 3 & $\begin{array}{l}\text { Ontario Home } \\
\text { Attack Risk } \\
\text { Assessment } \\
\text { (ODARA) }\end{array}$ & $\begin{array}{l}\text { ODARA is an actuarial tool that } \\
\text { indicates the likelihood that a } \\
\text { person who has already attacked } \\
\text { a home or dating partner will do } \\
\text { so again in the future. It also } \\
\text { predicts the amount of time } \\
\text { before a new attack and the } \\
\text { greater severity of new attacks. }\end{array}$ \\
\hline 4 & $\begin{array}{l}\text { Spouse Assault } \\
\text { Risk } \\
\text { Assessment } \\
\text { (SARA) }\end{array}$ & $\begin{array}{l}\text { SARA, developed at the British } \\
\text { Columbia Institute for the } \\
\text { Elimination of Domestic } \\
\text { Violence, is a "set of guidelines } \\
\text { for the content and process of a } \\
\text { thorough risk assessment". It } \\
\text { consists of } 20 \text { items derived } \\
\text { from the research literature on } \\
\text { domestic violence and the } \\
\text { clinical literature on male } \\
\text { violence. perpetrators of } \\
\text { domestic violence: a criminal } \\
\text { history, psychological } \\
\text { adaptation, a history of spousal } \\
\text { abuse, current characteristics of } \\
\text { offenses, and others (such as } \\
\text { harassment, torture). }\end{array}$ \\
\hline 5 & $\begin{array}{l}\text { CAADA-DASH } \\
\text { Risk } \\
\text { Identification } \\
\text { Checklist }\end{array}$ & $\begin{array}{l}\text { The CAADA-DASH Risk } \\
\text { Identification Checklist is a new } \\
\text { 24-item tool that is used in } \\
\text { England and Wales by leading } \\
\text { agencies that detect or respond } \\
\text { to domestic violence, such as } \\
\text { law enforcement, domestic } \\
\text { violence organizations, and } \\
\text { violent intervention programs, } \\
\text { healthcare, mental health } \\
\text { services. and a children's yard. }\end{array}$ \\
\hline
\end{tabular}

DVSI, ODARA, and SARA were designed to predict the likelihood of an offender re-attacking a current or former home or dating partner, while DA was designed to assess the risk of fatal or near-fatal violence for the victim. They differ in the risk factors indicated in the instrument, the intended use of the instrument, and the method of checking the instrument. For example, DA, DVSI, ODARA, and SARA have yes / no questions or clauses that relate to past criminal attacks and substance abuse. However, only DA has a strangulation issue that has been identified as a risk factor for killing women.

Other risk tools:

- The "Fatal Violence in the Family" (DVLAP) section of the Maryland Domestic Violence Assessment Network program uses 11 of the 20 questions asked in the Hazard Assessment in the "Fatal Screen" section. Law enforcement agencies use the Mortality Screen to identify high-risk victims and associate them with local lawyers.

- The Duluth Police Pocket Card adapted several key questions from risk assessment tools to help response officers ask open-ended questions (instead of yes / no questions) to victims. The responses are included in the narrative of the police report and are not intended to be considered as a valid risk assessment, but to describe to the court the potential danger to the victim.

- The Risk Guide for Practitioners contained in the Safety Plan is based not only on risk and hazard factors, but also on other research related to violence against women.

Of course, no tool can predict with certainty the risk of re-assault or death in cases of domestic violence. Tools should be seen as an aid in risk assessment, as well as for informing decision makers at points in the criminal justice process such as arrest, release on bail, sentencing, sentencing and probation.

The development of any country is largely determined by the public and state management system, decision-making mechanisms. It is imperative that the authorities contribute to solving the problems facing society, understand these problems, and soberly assess the possibilities of solutions.

\section{REFERENCES}

1. "O merah po korennomu sovershenstvovaniju dejatel'nosti $\mathrm{v}$ sfere podderzhki zhenshhin i ukreplenija instituta sem'i". Ukaz prezidenta Uzbekistan, PF-5325 02.02.2018. Aviable to: http://lex.uz/docs/3546745.

2. "O profilaktike bytovogo nasilija"ju Zakon Respubliki Uzbekistan, ID-658. 2018. Aviable to: https://regulation.gov.uz/ru/document/658

3. «O merah po sovershenstvovaniju sistemy social'noj reabilitacii i adaptacii, a takzhe profilaktiki semejno-bytovogo nasilija». Reshenie prezidenta Uzbekistan PP-3827 02.07.2018. Aviable to: http://www.lex.uz/ru/docs/3804813.

4. Azhgihina N.I., Abubikirova N.I. Molchanie pitaet nasilie, ili Chastnaja zhizn' rossijskoj zhenshhiny. Moscow: 2003. P.320.

5. Babaeva JI.B. Zhenshhiny Rossii v uslovijah social'nogo pereloma: rabota, politika, povsednevnaja zhizn'. Moscow: Refl-Buk, 1997. pp. 112-180.

6. Baskakova M.E. Ravnye vozmozhnosti i tendernye stereotipy na rynke truda. Noscow, 1998. - pp. 100-136.

7. Bopuar S. Votoroj pol. Moscow: Progress; Aletenja,1997

8. Fridan B. Zagadka zhenstvennosti. - M.: Progress, 1994.

9. Fridan B. Zhenskaja mistika. M.:1951.

10.Hasbulatova O.A. Rossijskaja tendernaja politika v XX stoletii: mify i realii. /O.A. Hasbulatova Ivanovo: Ivan. gos. un-t, 2005. -372s.

11.Hegaj M.N. Gendernye stereotipy i nasilie protiv zhenshhin. Aviable to: http://comrnunity.livejournal.eom/feministki/l 54603 .html.

12.Kollontaj A.M. Social'nye osnovy zhenskogo voprosa. Moscow.: «Znanie», 1909. - 220 s. 
13.Mjej R. Muzhchina i zhenshhina v.sovremennom mire: menjajushhiesja.roli i obrazy. V 2-h tt. Moscow: 1999. pp 89-289.

14.Mjej R. Sila.i nevinnost', Moscow: Smysl, 2001. - pp. 299-319.

15.Sillaste G.G. Social'naja diskriminacija zhenshhin kak predmet sociologicheskogo analiza. Socis.- 1997. No.12.

16.Solod D. Zhenshhina, a ne lichnost'? Kak menjajutsja voprosy gendernogo ravenstva $\mathrm{v}$ Uzbekistane. Aviable to: https://www.opendemocracy.net/ru/uzbekistan-gender-ineaulity-viole ncl.

17. The number of women (aged 15-49 years) who have been subjected, since the age of 15 years, to sexual abuse by persons who were not close partners (2014-2018) Aviable to: https://gender.stat.uz/en/v-group-en/1180-the-number-of-women-aged -15-49-years-who-have-been-subjected-since-the-age-of-15-years-to-s exual-abuse-by-persons-who-were-not-close-partners.

18. The number of women (aged 15-49 years) who have ever had a close partner who have been physically and / or sexually abused by an active or previous close partner in the last 12 months. Aviable to: https://gender.stat.uz/en/v-group-en/1179-the-number-of-women-aged -15-49-years-who-have-ever-had-a-close-partner-who-have-been-phy sically-and-or-sexually-abused-by-an-active-or-previous-close-partner -in-the-last-12-months1.

19.UN in Uzbekistan supports the Global Campaign Against Gender Based Violence. Aviable to: http://www.un.uz/eng/news/display/175.

\section{AUTHORS PROFILE}

Ziyaeva Holida Omonkul kizi obtained her Bachelors and Master's Degree in Social Work from The National University of Uzbekistan after named Mirzo Ulugbek, Tashkent city, Uzbekistan. She has published 2 Journals and 3 papers in both national and international conferences. 